\title{
Comparison of Soil Characteristics and Density by Non Nuclear Soil Density Gauge with Conventional Method
}

\author{
Pramod durgekar \\ Dept. of Civil Engineering, Girijabai sail institute of technology, Karnataka, India
}

\begin{abstract}
Soil is naturally occurring material that is used for the construction of pavements. Soil is a variable material and exhibits different properties in the different regions and becomes a challenge for the construction of roads sometimes. Hence detailed understanding of the nature of the soil in the site and its behavior as a subgrade material has to be properly assessed. Three types of soils are used for the present study namely, Black cotton soil, Gravelly sand and sandy soil. Their characteristics are assessed to decide its suitability as a road material. In-situ soil density measurement has been conventionally done using sand replacement and core cutter methods. There is an invent of a new gauge called the Non-nuclear soil density gauge which is getting popular nowadays in the determination of field density. In the present study an attempt is made to compare the densities obtained by the three different methods by varying the lift thickness of $150 \mathrm{~mm}$ and $300 \mathrm{~mm}$ as per MORT\&H specification. The compaction of the soil is done with a rammer of size $20 \mathrm{~cm} \times 15 \mathrm{~cm}$ with required number of blows. The density results obtained from the different approaches have been correlated and compared.
\end{abstract}

Keywords: Compaction, Core cutter, Correlation, Non- Nuclear soil density gauge, Sand Replacement test

\section{Introduction}

Compaction of soil is one of the most important aspects in road construction. Therefore, measurement of soil density and moisture content is used to control the compaction of soil at site. In situ determination of density and moisture content is greatly important in the construction of road subgrade so as to carry out the work speedily and accurately. There are various methods to monitor the compaction of soil. The most common method of determining the soil density at site is sand replacement method, core cutter method and rubber balloon method. These are the conventional method for determining the field compaction of soil. These method even though very common, they are laborious and the result obtained are not very accurate. The developments of Non nuclear soil density gauge have often made possible to determine the in-situ moisture content and the density of the compacted soil. Non Nuclear soil density gauge is currently the most widely used because of its simple operation and accuracy. The density measured by soil density gauge is based on the response of soil to the electromagnetic probing and compaction is measured based on the electrical sensing field to changes in electrical impedance of the material matrix.

\subsection{Importance of soil compaction in the field}

Compaction of soil is process of increasing the density of the soil by mechanical means by packing the soil particle closer together which will result in the reduction of air voids and also to obtain the homogeneous soil mass having improved soil property. Compaction of soil brings many desirable changes in soil property such as follows.

a) Compaction of soil increases the shear strength

b) Increases the density of the soil and reduces the permeability of soil

c) Reduces the uneven settlement of the soil during the service

\section{Materials And Method}

In the present study three types of soils are collected from different places of Karnataka and are considered to understand how they affect the density achieved. The Type-1 is the Black cotton soil obtained from a site in North Karnataka. The index properties were determined and are tabulated in Table 3.1 the gradation obtained by wet sieve analysis and is shown in Table 3.1 Based on these results and according to HRB classification, this soil is classified as $\mathrm{CH}$, Type -2 soil is Gravelly sand which is obtained from a site near Tumkur. The index properties were determined and are tabulated in Table 3.1 the gradation obtained is shown in Table 3.1 Based on these results and according to HRB classification, this soil is classified as GC, Type -3 soil is Sandy soil which is obtained from a site near Tumkur. The index properties were determined and are tabulated in Table 3.1 the gradation obtained is shown in Table 3.1 Based on these results and according to HRB classification, this soil is classified as SC. 


\subsection{Details of Tests Conducted}

In order to meet the objectives of the present investigation tests are conducted as per the procedures stipulated in I.S. Code of Practice on Three soils listed in the Table 3.1. The following tests are conducted Grain Size Distribution, Liquid Limit, Plastic Limit, and Modified Compaction Test, California Bearing Ratio test (CBR) and Field Density test (i.e. Non-nuclear soil Density gauge, Sand replacement and Core cutter)

\subsection{Methodology}

Procedure followed for Prototype Sub grade

1. The test pit measures $1.5 \mathrm{~m} \times 1.5 \mathrm{~m}$ square and having a depth of $0.5 \mathrm{~m}$ is prepared.

2. The test pit is filled with soil to a loose thickness of $20 \%$ more than the aimed compacted lift thickness. i.e. for example, For lift thickness of $150 \mathrm{~mm}$, loose thickness of $180 \mathrm{~mm}$ is laid and compacted.

3. The soil is spread uniformly and the measurements of loose thickness are taken at several locations.

4. The initial moisture is checked and the required water is added to achieve the predetermined OMC in the test pit.

5. The soil is mixed manually to achieve uniform moisture content. It is measured once again by rapid moisture meter method using Calcium carbide.

6. Once the required moisture is achieved with $\pm 2 \%$ deviation, the soil is graded manually and ready for compaction.

7. Here, for the prototype sub grade, the compactive effort in the form of number of blows, which is pre-calculated based on density achieved in the laboratory for modified Proctor compaction.

8. The required number of blows is given manually with a rammer of size $20 \mathrm{~cm} \times 15 \mathrm{~cm}$ such that the entire test pit is covered and compacted uniformly.

9. After the compaction is completed, the field density achieved is measured by, sand replacement method, core cutter method and Non nuclear soil density gauge at three locations

\section{Indentations And Equations}

Calculation of Compaction effort for the soil of lift thickness $150 \mathrm{~mm}$ and $300 \mathrm{~mm}$

Total weight of soil $=$ volume $*$ density

$$
\begin{aligned}
& =(150 * 75 * 18) * 1.630 \\
& =330.07 \mathrm{~kg}
\end{aligned}
$$

Number of blows given in laboratory compaction test is 25

Present volume of mould $=(150 * 75 * 18)$

Therefore number of blows $=\mathrm{x}$

$$
=202500 \mathrm{~cm}^{3}
$$

$$
\begin{aligned}
1630 & =25 \\
202500=x &
\end{aligned}
$$

Total number of blows is 3106

Size of the rammer used for field compaction $20 \mathrm{~cm} \times 15 \mathrm{~cm}$

One cycle of compaction $=(150 / 20) *(75 / 15)$

\begin{tabular}{|c|c|c|c|}
\hline \multirow[t]{2}{*}{ Test Conducted } & \multicolumn{3}{|l|}{ Test Result } \\
\hline & Black cotton soil & Gravelly Sand soil & Sandy soil \\
\hline Gradation of soil & $\begin{array}{l}\text { Gravel }=2.78 \% \\
\text { Sand }=6.26 \% \\
\text { Silt }+ \text { clay }=90.96 \% \\
\text { IS soil Classification }=\mathrm{CH}\end{array}$ & $\begin{array}{l}\text { Gravel }=29.17 \% \\
\text { Sand }=37.89 \% \\
\text { Silt }+ \text { clay }=32.94 \% \\
\text { IS soil Classification = GC }\end{array}$ & $\begin{array}{l}\text { Gravel }=26.54 \% \\
\text { Sand }=54.48 \% \\
\text { Silt }+ \text { clay }=18.98 \% \\
\text { IS soil Classification = SC }\end{array}$ \\
\hline \multirow[t]{2}{*}{ Test Conducted } & \multicolumn{3}{|l|}{ Test Result } \\
\hline & Black cotton soil & Gravelly Sand soil & Sandy soil \\
\hline Atterberg's limits & $\begin{array}{l}\mathrm{LL}=83.50 \% \\
\mathrm{PL}=43.03 \% \\
\mathrm{PI}=40.07 \%\end{array}$ & $\begin{array}{l}\mathrm{LL}=23.41 \% \\
\mathrm{PL}=14.57 \% \\
\mathrm{PI}=8.84 \%\end{array}$ & $\begin{array}{l}\mathrm{LL}=\mathrm{Np} \\
\mathrm{PL}=\mathrm{Np} \\
\mathrm{PI}=-\end{array}$ \\
\hline Modified proctor test & $\begin{array}{ll}\text { Optimum } & \text { Moisture } \\
\text { Content } & \\
=20.55 \% & \\
\text { Maximum Dry } & \text { Density = } \\
1.63 \mathrm{gm} / \mathrm{cm}^{3} & \end{array}$ & $\begin{array}{l}\text { Optimum Moisture Content } \\
=10.25 \% \\
\text { Maximum Dry Density = } \\
1.92 \mathrm{gm} / \mathrm{cm}^{3}\end{array}$ & $\begin{array}{l}\text { Optimum } \\
\text { Content } \\
=10.78 \% \\
\text { Maximum Dry Density = } \\
1.97 \mathrm{gm} / \mathrm{cm}^{3}\end{array}$ \\
\hline California Bearing Ratio & $1.34 \%$ & $15.21 \%$ & $13.09 \%$ \\
\hline
\end{tabular}

$$
=38 \text { times }
$$

Therefore, total number of time $=3106 / 38=82$ time

\section{Figures And Tables}

Table 4.1 laboratory Test result on soil 


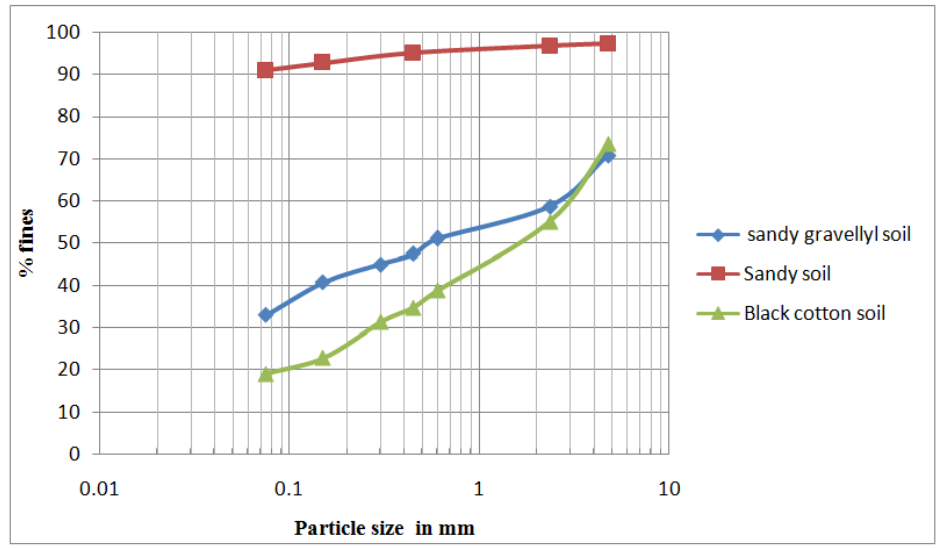

Fig 4.1 Gradation of soil

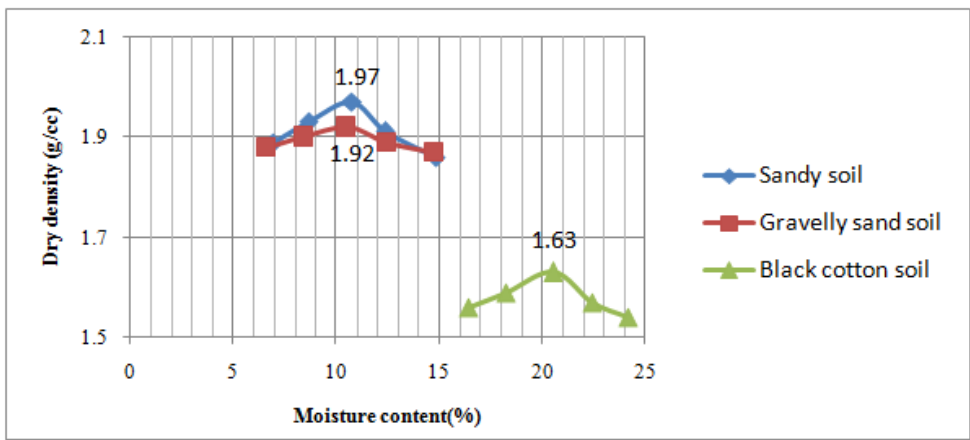

Fig 4.2 OMC and MDD for Sandy soil, Gravelly sand soil and Black cotton soil

Table 4.2 Field Density Test Result

\begin{tabular}{|c|c|c|c|c|c|c|}
\hline \multicolumn{7}{|c|}{ Test Result of Black cotton soil } \\
\hline \multirow{2}{*}{$\begin{array}{l}\text { Lift thickness } \\
\text { Method used }\end{array}$} & \multicolumn{3}{|l|}{$150 \mathrm{~mm}$} & \multicolumn{3}{|l|}{$300 \mathrm{~mm}$} \\
\hline & $\begin{array}{l}\text { Non nuclear } \\
\text { soil density } \\
\text { gauge }\end{array}$ & $\begin{array}{l}\text { Sand } \\
\text { replacement }\end{array}$ & $\begin{array}{l}\text { Core } \\
\text { cutter }\end{array}$ & $\begin{array}{l}\text { Non nuclear } \\
\text { soil density } \\
\text { gauge }\end{array}$ & $\begin{array}{l}\text { Sand } \\
\text { replacement }\end{array}$ & $\begin{array}{l}\text { Core } \\
\text { cutter }\end{array}$ \\
\hline \% compaction & 93 & 82.76 & 81.22 & 92.7 & 83.88 & 82.99 \\
\hline Dry density & 1.843 & 1.628 & 1.633 & 1.83 & 1.653 & 1.633 \\
\hline \multicolumn{7}{|c|}{ Test Result of Gravelly Sand soil } \\
\hline Lift thickness & \multicolumn{3}{|c|}{$150 \mathrm{~mm}$} & \multicolumn{3}{|l|}{ 300mm } \\
\hline \% compaction & 78.70 & 87.40 & 88.00 & 77.50 & 83.84 & 85.55 \\
\hline Dry density & 1.666 & 1.855 & 1.867 & 1.642 & 1.778 & 1.814 \\
\hline \multicolumn{7}{|c|}{ Test Result of Sandy soil } \\
\hline Lift thickness & \multicolumn{3}{|l|}{$150 \mathrm{~mm}$} & \multicolumn{3}{|l|}{ 300mm } \\
\hline \% compaction & 85.30 & 87.94 & 86.82 & 84.30 & 86.93 & 86.27 \\
\hline Dry density & 1.862 & 1.893 & 1.871 & 1.832 & 1.897 & 1.888 \\
\hline
\end{tabular}

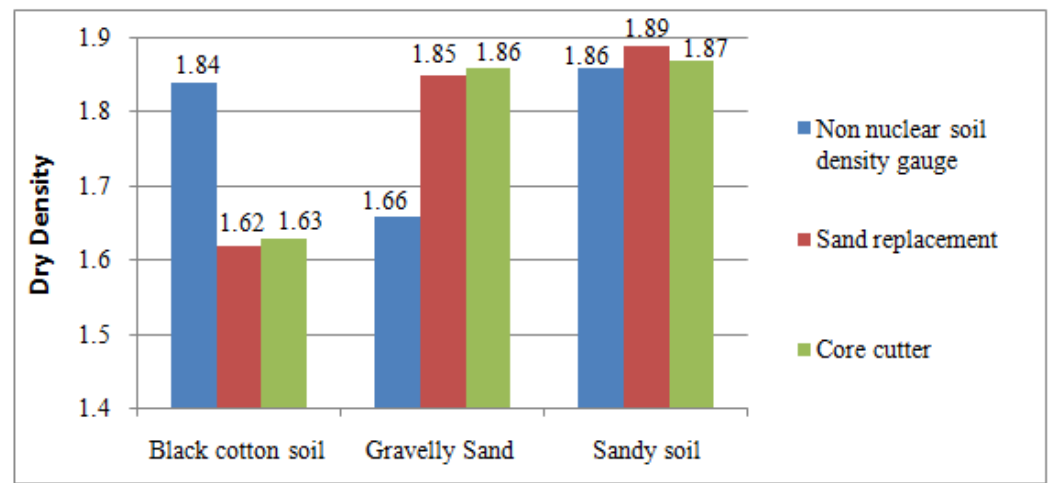

Fig 4.3 Comparison of Dry density of soil for lift thickness of 150mm 


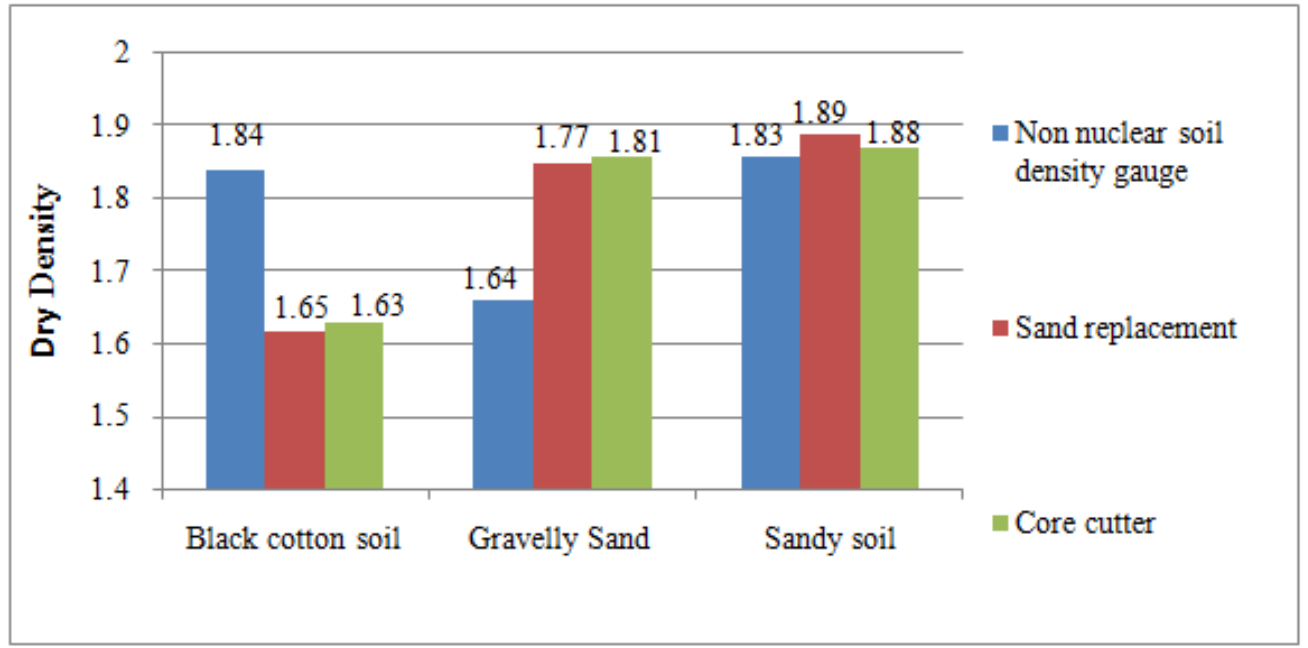

Fig 4.4 Comparison of Dry density of soil for lift thickness of 300mm

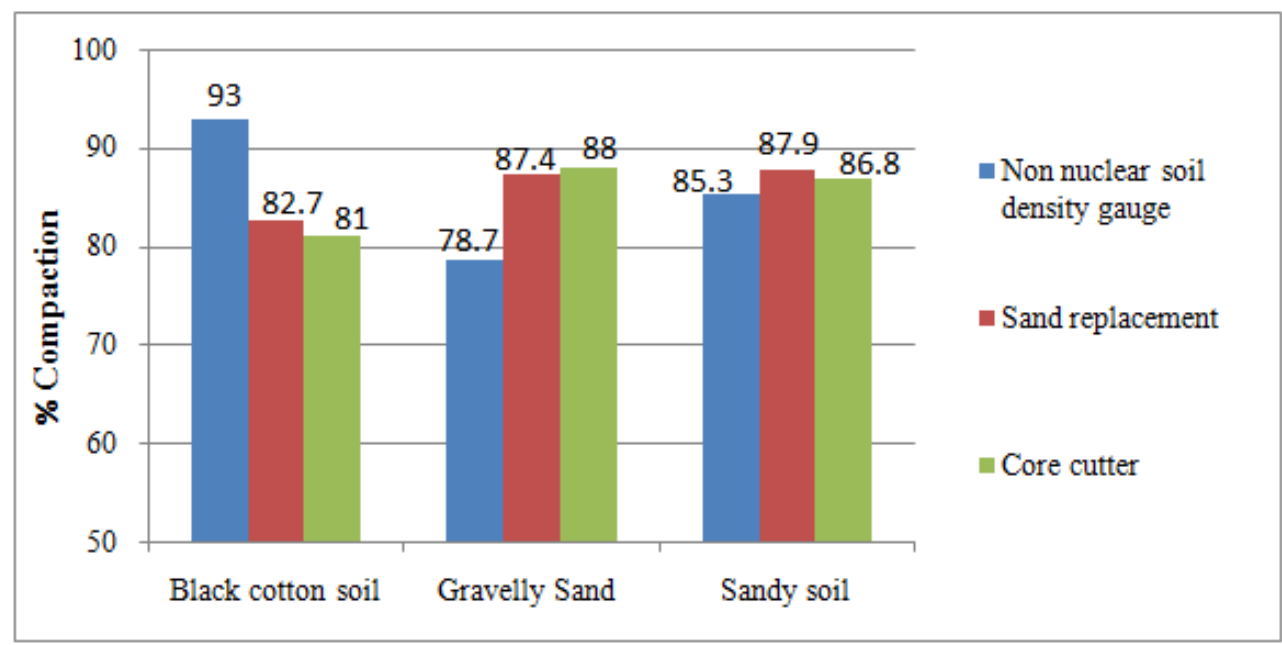

Fig 4.5 Comparison of \% Compaction of soil for lift thickness of 150mm

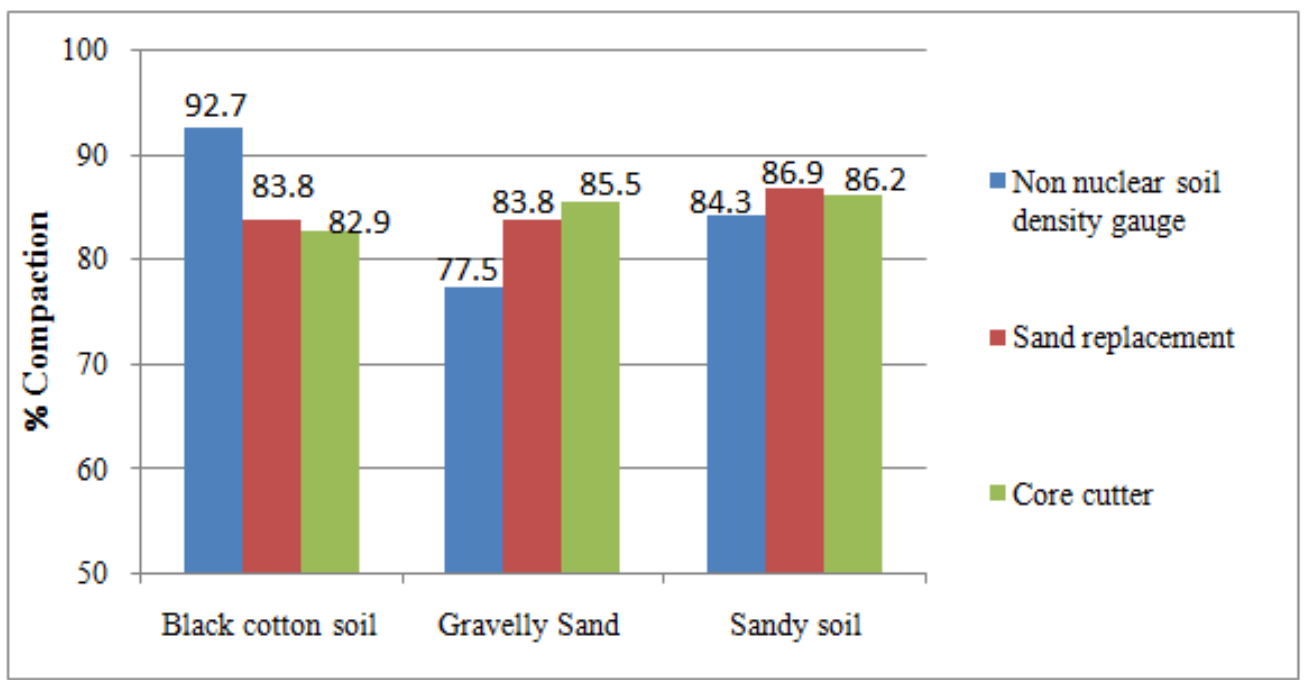

Fig 4.6 Comparison of \% Compaction of soil for lift thickness of $300 \mathrm{~mm}$ 
Table 4.3 Correlation of the dry density

\begin{tabular}{|l|l|l|l|l|l|l|l|l|}
\hline Black cotton soil & \multicolumn{3}{l|}{ Gravelly sand soil } & \multicolumn{2}{l|}{ Sandy soil } \\
\hline $\begin{array}{l}\text { Non } \\
\text { nuclear } \\
\text { soil density } \\
\text { gauge }\end{array}$ & $\begin{array}{l}\text { Sand } \\
\text { replacement }\end{array}$ & $\begin{array}{l}\text { Core } \\
\text { cutter }\end{array}$ & $\begin{array}{l}\text { Non nuclear } \\
\text { soil density } \\
\text { gauge }\end{array}$ & $\begin{array}{l}\text { Sand } \\
\text { replacement }\end{array}$ & $\begin{array}{l}\text { Core } \\
\text { cutter } \\
\text { roil nuclear } \\
\text { density } \\
\text { gauge }\end{array}$ & $\begin{array}{l}\text { Sand } \\
\text { replacement }\end{array}$ & $\begin{array}{l}\text { Core } \\
\text { cutter }\end{array}$ \\
\hline 1.51 & 1.372 & 1.337 & 1.511 & 1.679 & 1.69 & 1.678 & 1.698 & 1.681 \\
\hline 1.518 & 1.379 & 1.331 & 1.502 & 1.67 & 1.686 & 1.685 & 1.684 & 1.677 \\
\hline 1.551 & 1.385 & 1.342 & 1.507 & 1.674 & 1.699 & 1.661 & 1.69 & 1.684 \\
\hline 1.512 & 1.367 & 1.349 & 1.479 & 1.616 & 1.624 & 1.66 & 1.703 & 1.696 \\
\hline 1.504 & 1.351 & 1.324 & 1.488 & 1.609 & 1.642 & 1.649 & 1.721 & 1.695 \\
\hline 1.526 & 1.364 & 1.339 & 1.484 & 1.609 & 1.633 & 1.635 & 1.716 & 1.694 \\
\hline
\end{tabular}

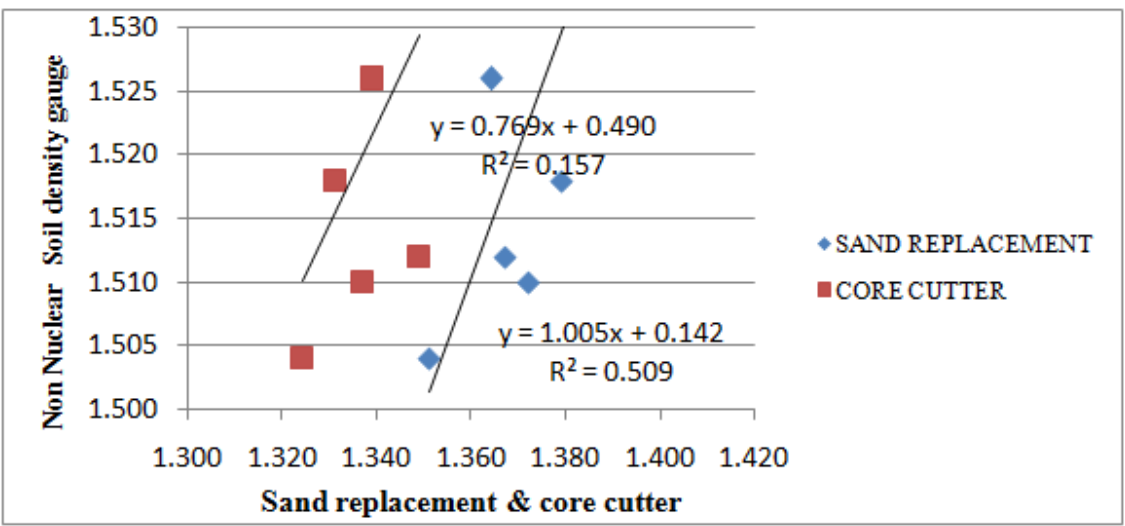

Fig 4.7 Typical co-relation obtained for dry density for Black Cotton soil

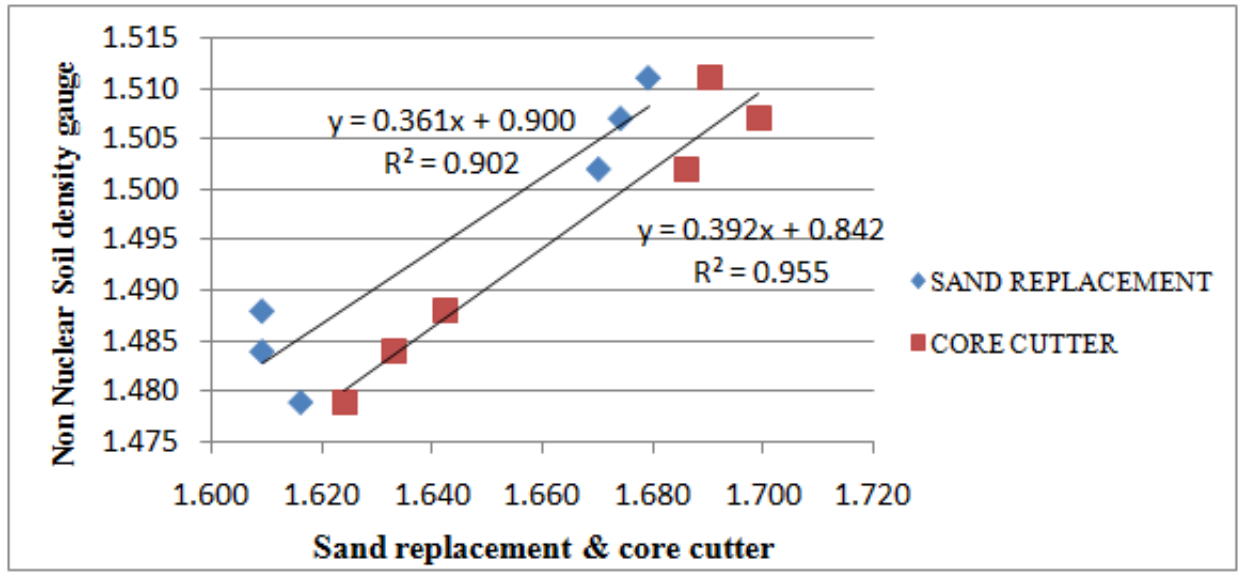

Fig 4.8 Typical co-relation obtained for dry density for Gravelly Sand

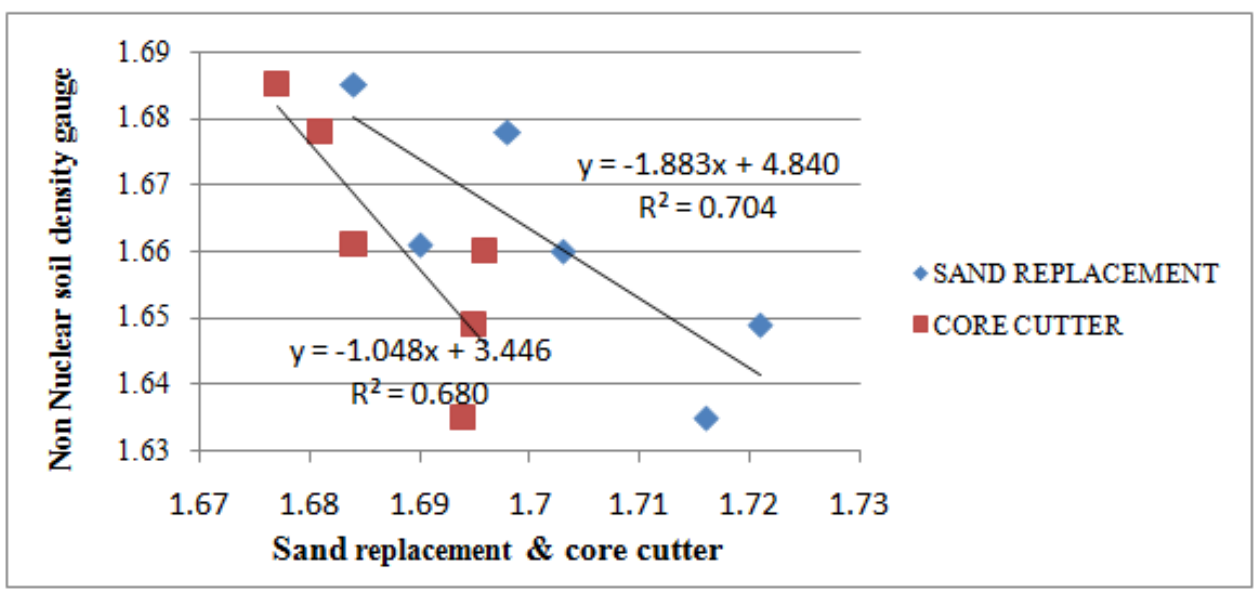

Fig 4.9 Typical co-relation obtained for dry density for Gravelly Soil 


\section{Conclusion}

The Non-nuclear soil density gauge which is a quick method of determining in-situ density. In the present study Non-nuclear soil density gauge was used to compare its accuracy. It was observed that the variations in the field density measurement for Black cotton soil only may be attributed to its loss of strength of the sub-grade and difficult to handle as a road material. However for the other two soils the density measured by the Non Nuclear Soil Density Gauge is in close correlation with the sand replacement and the core-cutter methods. In the field, when density was measured for the black cotton soil by the SDG gives higher density of $11 \%$ but however a variation of $16 \%$ has been reported for other two soils and analyzed. Both non nuclear density gauges showed that the technology available today does show some promise, but that there are issues to resolve from both a results and field application perspective. More testing and research is needed to establish.

The Non-nuclear soil density gauge is the best field device based on precision and accuracy for measuring the dry density of soils. However, the accuracy of the device is highly dependent upon calibration with an adjacent field sample tested The Non-nuclear soil density gauge has the capability of becoming a viable Quality Control device. However, inconsistencies are occurring when trying to accurately obtain Non-nuclear soil density gauge dry density when compared to Sand replacement and core cutter During a field evaluation, the Non-nuclear soil density gauge outputted data were compared to sand replacement method and Core Cutter Method

\section{Recommendations for Further Research:}

More number of field tests is to be performed with the Non-nuclear soil density gauge and calibration of instrument is to be done by comparing test result obtained by Non nuclear soil density gauge with sand replacement and core cutter. The parameters such as Dry density, Wet density, Moisture content and percentage of compaction should be taken into the consideration during calibration of Non nuclear soil density gauge. After the complete calibration of the Non nuclear soil density gauge the field test is to be conducted and result has to compare with other conventional methods.

\section{Acknowledgements}

I would like to express my gratitude and sincere acknowledgment to my Dr. Suresh D. Mane, Principal, Girijabai sail institute of technology, karwar.He continuously helped with his valuable suggestions and encouragement during the entire project.

I am grateful to prof. Vaibhav Shirodkar, Head of civil engineering department for providing me the necessary help and encouragement whenever needed which has resulted in the success of my project.

I would also like to thank all the staff member of our department, without whose constructive suggestion and valuable advice, the simple idea which has been borne by me, would not been able to blossom forth to give such a beautiful bloom.

Last but not the least; I am grateful to all my family member and friends for their direct and indirect constant moral support through the project.

\section{References}

[1] Yong K. Cho, Koudous Kabassi, and Chao Wang, "Non-Nuclear Methods of Evaluation for Soil Quality control and Quality assurance in Highway Pavement Construction" KICEM Journal of Construction Engineering and Project Management, 2012, 2-5

[2] Ashley Adams, Ruth Tobin and Manal Salem "Evaluation of Non-Nuclear Methods for Compaction Control" Center for Transportation Research University of Texas at Austin, July 2007, 34-65

[3] Selim altun, A. Alper Sezer "Non-Nuclear Density Gauge Comparative Study" Ohio Research Institute for Transportation, August 2005, 21-37.

[4] Mohammad S Islam, Stacy G. Williams "Non-Nuclear Methods for HMA Density Measurements" Department of Civil Engineering University of Arkansas June 2008, 1-5.

[5] Jeff brown, Gerald Roosevelt Maregesi "Validation of Nuclear Gauge Density-Meter Readings against Sand Replacement Method” Advanced Engineering Solutions Ltd, 50-54.

[6] Mohammad S Islam, Joshua E. R. Wells "Calibration of Non-Nuclear devices for Construction Quality Control of Compacted Soils” University of Kentucky, April 18, 18-33

[7] Bryce Simons, Nahid Sultana, Asif Ahmed "Evaluation of Soil Compaction Measuring Devices" Civil Engineering Research Institute Daniel Vetter, March 2005, 2-76.

[8] Mariely Mejías-Santiago, Ernest S. Berney IV and Chase T. Bradley “ Evaluation of a Non-Nuclear Soil Density Gauge on Fine-Grained Soils" US Army Engineer Research and Development Center May 2013, 29-41.

[9] Deepika.Chukka1, Chakravarthi.V.K "Evaluation of Properties of Soil Sub grade Using Dynamic Cone Penetration Index - A Case Study” PG student, Department of Civil Engineering, GMR Institute of technology, Andhra Pradesh, $1-5$

[10] Charles S. Gresser, "Soil compaction and stability" Int. Journal of Engineering Research and Applications, May 2014, 6-16. 